УДК 340.12

DOI https://doi.org/10.51989/NUL.2021.4.40

\title{
РЕЛЯЦІЙНА ТЕХНІКА ГЕРМАНА ДАУБЕНШПЕКА ТА ОСНОВНІ ФОРМИ ПРАВОЗАСТОСУВАННЯ
}

\section{Степенюк Олег Григорович,}

аспірант юридичного факультету

Чернівецького національного університету імені Юрія Федьковича

У статті йдеться про оригінальну навчальну інтердисциплінарну методику опрацювання правової справи (реляційну техніку), яка знайшла свій класичний вираз у посібнику Германа Даубеншпека (1831-1915) «Referat, Votum und Urtheil: eine Anleitung für praktische Juristen im Vorbereitungsdienst», перше видання якого мало місце у 1884 в Берліні у видавництві Vahlen, нараховуючи 154 сторінки, а останнє - 35 зі змінами і доповненнями, продовжене іншими редакторами, 514 сторінок - у 2013 році.

Метою статті є опис і критичний аналіз згаданої в попередньому абзаці реляційної техніки у світлі двох основних - за Робертом Алексі - форм правозастосування, а саме з погляду субсумції і зважування.

У нашій роботі розглядаються три питання: по-перше, передісторія та історія видань праці Г. Даубеншпека, їі структура й окремі особливості. Зокрема, констатується, що реляційна техніка складається в судовій діяльності приблизно з 1500 року, а в останні 14 десятиліть вона була актуальною в кайзерівській Німеччині, Веймарській республіці, в націонал-соціалістичний період та післявоєнний період і є такою в наші дні в рамках двоступеневої юридичної освіти Німеччини.

По-друге, питання про філологічну і субсумційну природу оригінальної реляційної техніки Г. Даубеншпека. Зокрема, констатується, що експертний та судовий стилі опрацювання правової справи (як методологічні та матеріально-правові аспекти реляційної техніки) є, власне кажучи, двома можливими способами юридичного і логічного аналізу застосування норм, які належним чином виражені в чинному законодавстві, тобто так званих закритих норм.

По-третє, щодо делібераційного потенціалу згаданої техніки. Тут йдеться про ті питання, які не можуть бути вирішенні на основі субсумції, тобто про застосування шляхом зважування відкритих правових норм.

У підсумку констатовано, що згадана реляційна техніка може бути реципована в юридичній навчальній практиці України (з відповідною адаптацією і розвитком, які мають пряме відношення до основних форм правозастосування). Ї̈̈ найкраще розроблені аспекти спираються на логічну структуру субсумції, тобто підведення факту під норму, і в цьому сенсі $\epsilon$ інтерсуб'єктивними. Водночас ця техніка має відкриті питання, пов'язані з такою формою правозастосування, як зважування. Розроблення останнього аспекту може надати нове життя реляційній техніці як у Німеччині, так і в Україні.

Ключові слова: Hermann Daubenspeck, реляція і реляційна техніка, субсумція, зважування, форми правозастосування, юридична методологія, філологія права.

\section{Stepeniuk Oleh. Hermann Daubenspeck's relational technology and the basic forms of law enforcement}

The article under studies deals with the new educational interdisciplinary method of approaching a legal proceeding (relational technology), which was first mentioned in the manual by Hermann Daubenspeck (1831-1915) "Referat, Votum und Urtheil: eine Anleitung für praktische Juristen im Vorbereitungsdienst". The first edition of the latter manual was published in Berlin, in 1884 by the publishing house Vahlen. It had 154 pages, whereas the last edition (along with changes and supplements, as well as continued by other editors) was released in 2013 and contained 514 pages.

The objective of the article is to describe and critically analyze relational technology within the two major (according to Robert Alexy) forms of law enforcement - subsumption and balancing.

The paper under discussion considers three issues: firstly, the prehistory and history of publishing H. Daubenspeck's work, its structure and certain peculiarities. Particular emphasis is laid on the fact that relational technology has been in the judiciary since about 1500, and in 
the last 14 decades, it has been relevant in the Kaiser's Germany, the Weimar Republic, during the National Socialist and postwar periods, as well as preserves its significance today, within the two-level legal education of Germany.

Secondly, the article points out the philological and subsumption nature of H. Daubenspeck's relational technology. To be more specific, it states that expert and judicial styles of considering the legal proceeding (as the methodological and substantive aspects of relational technology) are the possible ways of legal and logical analysis of the application of norms that are properly expressed in current legislation.

Thirdly, the paper dwells on a deliberative potential of relational technology. It covers the problems that cannot be solved on the basis of subsumption, but by means of balancing the open legal norms.

In conclusion, the article under studies claims that relational technology may be reciprocated in the legal educational practice of Ukraine (with appropriate adaptation and development, which are directly related to the main forms of law enforcement). Its best developed aspects rely on the logical structure of subsumption, whereby the fact is brought under the norm. On the other hand, this technology is not capable of answering numerous questions related to such a form of law enforcement as balancing. The development of the latter aspect can give new life to relational technology in both Germany and Ukraine.

Key words: Hermann Daubenspeck, relation and relational technology, subsumption, balancing, forms of law enforcement, juridical methodology, philology of law.

80-ті роки позаминулого, тобто XIX століття, цікаві в плані юридичної методології двома подіями. У другій половині цих років, а саме в 1887 році, розпочинав свій творчий шлях Євген Ерліх, зусиллями якого з часом була заснована соціологія права. А за три роки до цього, тобто в 1884 році, вийшло друком перше видання посібника зі складання судових та інших правових рішень, який називається «Доповідь, експертний висновок, рішення: керівництво для юристів-практикантів під час стажування» [1] Германа Даубеншпека (1831-1915), який став зразковим для філології права, хоча таке найменування й не стало настільки поширеним, як соціологія права. Відзначимо, що Є. Ерліх, який навчався в Чернівецькому, Львівському і Віденському університетах, імовірно, міг цим посібником користуватися. Крім того, якщо головний твір $€$. Ерліха «Заснування соціології права» вийшов друком з 1913 року тільки 4 рази, то згадана праця Даубеншпека, продовжена іншими редакторами, вийшла 35 разів. Останнє видання ії було в 2013 році [2].

У посібнику Г. Даубеншпека, враховуючи всі його видання, містяться оригінальні й цікаві з погляду української навчальної практики положення щодо методики опрацювання правової справи на основі так званої реляційної техніки, які можуть бути запозичені з метою поліпшення сучасної української юридичної освіти. Тому звер- нення до такої теми є актуальним і важливим не тільки теоретично, але й на практиці.

На жаль, ні власне реляційна техніка, ні згаданий вище посібник, який давно став візитною карткою німецької юридичної освіти, не привернули належної уваги українських юристів. Тому ця стаття фундує певний напрям наукового дослідження, який нашаровується іншими публікаціями на дисертаційну тему «Герман Даубеншпек і матеріально-правова реляційна техніка» (науковий керівник С.В. Савчук).

Інша ситуація складається в Німеччині, де реляційна техніка і творчий здобуток Г. Даубеншпека приковують до себе значну увагу. Йдеться про роботи таких авторів, як: Л. Гуссек, Ф. Ранієрі, К.-Ф. Штукенберг та ін. Слід окремо відзначити редакторів згаданого посібника, який з часом ставав все об'ємнішим, таких як П. Заттельмахер, У. Зірп та ін.; а також монографії Я. Шаппа та Р. Ціппеліуса, які перекладені російською і українською мовою, оскільки вони будуються з використанням реляційної техніки. Окремо відзначимо тих авторів, які досліджували відношення субсумції і зважування (Р. Алексі, Г. Штюк та ін.) та питання правіжного методу (Є.М. Шаллер, Д. Медікус та ін).

Водночас в Україні існує надійна підоснова для спеціального дослідження матеріально-правових аспектів реляційної техніки, з акцентом на напрацювання, започатковані Г. Даубеншпеком. 
Деякі її аспекти містяться в роботах професора Р.А. Майданика (експертний стиль), канд. юрид. наук В.В. Трутня (правіж, тобто загальна вимога, правіжний склад, основні й допоміжні норми (нормативний айсберг), принцип матеріальної економії), А.Г. Павлюка (відведення, або абсолютне заперечення); професорів П.О. Недбайла (правозастосування), С.І. Максимова (Алексіана: позитивна характеристика, переклади; правова реальність), П.М. Рабіновича (права людини, оцінка), С.П. Рабіновича (юснатуралізм, принцип пропорційності, чинність права), С.П. Погребняка, О.О. Уварової, А.М. Колодія (окремі питання аналізу правових принципів) та ін.

Метою статті $\epsilon$ опис і критичний аналіз згаданої вище реляційної техніки у світлі двох основних - за Робертом Алексі форм правозастосування, а саме з погляду субсумції і зважування. Для досягнення поставленої мети ми намітили виконати три завдання, а саме: по-перше, описати передісторію та історію видань праці Г. Даубеншпека, її структуру і окремі особливості; по-друге, показати філологічну та субсумційну природу оригінальної реляційної техніки Г. Даубеншпека, по-третє, з'ясувати делібераційний потенціал згаданої техніки.

1. Для розуміння подальшого викладу слід взяти до уваги таке. Суд вищих інстанцій, як відомо, може мати колегіальний характер. У такому разі теоретично існує дві можливості опрацювання суддями правової справи: або зі справою всі судді знайомляться однаковою мірою, або призначається суддя-доповідач, який за певною процедурою готує справу до розгляду. Реляційна техніка має тісне відношення до останнього способу розгляду судової справи. Якщо звернути увагу на заголовок посібника Г. Даубеншпека - «Доповідь, експертний висновок, рішення», то він якраз і передає етапи підготовки реляції: доповідь про обставини справи, підготовка експертного висновку суддею-доповідачем про можливе вирішення справи по суті і власне формулювання судового рішення.

Історія такої техніки-процедури досить цікава. Так, Ф. Ранієрі зазначає, що «реляційна техніка бере свій початок у появі письмового судового процесу в континентальній Європі з часів Середньовіччя. Особливо яскраво виражений ії̈ розвиток у практиці німецького Рейхскаммергеріхта уже з XVI століття. Письмовість і непрямий характер провадження в римському загальному судовому процесі, а також колегіальна структура Рейхскаммергеріхта в істотний спосіб накладають свій відбиток на техніку і стиль актової реляції. У центрі суддівського завдання асесора в Рейхскаммергеріхті перебуває складання реляції із процесуальних актів (матеріалів справи - О.С.). <...> Необхідність інформування колегіального суду про судовий процес зробила потрібним те, що асесор як релятор готує реферат, так зв. реляцію, про зміст письмових процесуальних актів і пропонує колегам. Правила судочинства в Каммергеріхті від 1500 і 1555 року уже згадують актову реляцію. <...> Матеріальне оформлення у разі складання залишається полишеним на правила із практики і традиції. Уже в XVI столітті для цього розробляються суворі правила побудови. Такий комплекс правил перебуває, мабуть, у взаємозв'язку з методичною традицією консіліаторів mos italicus і загальноправовою навчальною традицією того часу. Навчальна мета перебуває тут однозначно на передньому плані. Подібну навчальну функцію виконують, вочевидь, також численні друковані зібрання актових реляцій» [3, с. 1157].

Зазначене вище служило історичним тлом для появи в передостанньому десятилітті XIX століття праці Г. Даубеншпека, причому потрібно врахувати, що незадовго до того в Німеччині (приблизно в середині XIX ст.) відбувся перехід від письмового судового провадження до усного, в рамках якого власне судова функція реляції зрештою зійшла нанівець, а навчальна, навпаки, посилилась. Саме така ситуація і має місце в Німеччині в останні вже більш, ніж півтора століття.

За відповідні десятиліття робота Г. Даубеншпека була багато разів перевидана як самим автором, так і її наступними редакторами. Так, Л. Гуссек у статті «До реляції і раціональності суддівського вирішування. 125 років (праці) Даубеншпек-Заттельмахер: Доповідь, експертний 
висновок і рішення» (2010) [4] характеризує особливості окремих видань таким чином:

- мовні настанови «суцільно такого, що само собою зрозуміле» уже в праці Даубеншпека від 1884 року;

- розширена претензія щодо реляційної техніки цивільно-правового робочого методу як «такого» завдяки Заттельмахеру з 1929 року;

- повторне введення субсумції і силогізму до викладу суддівського рішення в переробленні Зірпсом від 1972 року;

- поширення цього посібника на професію адвоката зусиллями Шушке з 1994 року в процесі нового регулювання навчання юристів [4, с. 84].

Слід відзначити континуальність видань від кайзерівської імперії до наших днів. Наведемо структуру посібника за виданням дев'ятим 1905 року [5]. Робота вже містить 322 сторінки, на відміну від 154 сторінок першого видання чи 514 сторінок останнього. Вона складається, як можна здогадатися, із трьох частин, а також вступу і додатку. Перша частина називається «Доповідь (реферат)», друга «Правовий експертний висновок (вотум)», третя - «Рішення» [5, с. III-IV].

I знову для того, щоб зрозуміти, про що йдеться в цих розділах, потрібно повернутися до статті Ф. Ранієрі й розглянути структуру судової реляції:

Так, Ф. Ранієрі відзначає, що «настанови для підготовки актової реляції і вотума відповідають в XVI і XVII столітті майже повністю уніфікованій структурі: в основному цьому сприяють суворі правила щодо логічної і синтаксичної побудови і щодо формулювання вотума. Зокрема, в XVI столітті від настанови до настанови варіюється число і підрозділяння запропонованих етапів побудови. Проте практика Рейхскаммергеріхта залишається при цьому в Німеччині без винятку авторитетною як взірець. Найчастіше реляція містить такі складові частини:

1. Species facti. Під цим розуміються обставини, які лежать в основі процесуального протистояння. До цього побудовного пункту належить обговорення компетенції суду, легітимації сторін і прокураторів (повірених у справах - О.С.), а також питання, чи відбулися виклики відповідно до встановленого порядку.

2. Historia processus. Під цим найчастіше розуміється короткий перелік різних етапів провадження в попередніх інстанціях, а також в апеляційному провадженні в Каммергеріхті (історія судового процесу).

3. Extractus actorum. Тут мають на увазі відтворення заяв сторін. Воно відбувається 3 якнайбільшою докладністю і частково в оригіналі з відтворенням клопотання (Libell) позивача, позовної заяви з прохальним пунктом позовної заяви, а також потім клопотання (Libell) відповідача з його зустрічною заявою. За цим йшли услід засоби доведення. Якщо документи $\epsilon$ в наявності, то вони мусять додаватися в оригіналі; те саме має значення для rotula testium.

4. Votum. Тут мають на увазі правові експертні висновки щодо порушених сторонами правових питань. Також тут побудова юридичних обговорень дотримується суворих правил.

a) Substantia actionis. Тут виразно виявляється акціонно-правовий спосіб мислення юристів із загальноправової епохи; запитують характерно насамперед не про норму, застосовну до справи, а про підставу позову, яка може підтримати домагання позивача (quae sit actio). Ці (згадані вище) учбові і навчальні праці $\epsilon$, отже, тим ціннішими, що вони демонструють глибоку структуру способу мислення й аргументації тодішніх загальноправових практиків права. Це акціонно-правове мислення змушує до кваліфікації правової справи і до строгої субсумції. Це характеризує спосіб мислення континентально-європейських юристів дотепер.

b) An probata. Тут перевіряється, зокрема, те, чи доведені наведені позивачем факти i, отже, чи обґрунтовані твердження позивача.

c) An elisa. Якщо твердження позивача доведені, то необхідно докладно зупинитися на аргументах захисту відповідача і його доказах. Зокрема, тут потрібно перевірити, чи заявляються, незважаючи на успішне доведення з боку позивача, заперечення від відповідача, які розвіюють твердження позивача.

d) Пропозиція рішення. Реляція і вотум повинні завершуватися пропозицією 
референтом щодо вирішення. Тому до цього належить тенор (резолютивна частина - О.C.) запропонованого рішення, разом з усіма формальностями, проте, як тоді було звично, без обґрунтування» [3, с. 1158-1159].

Викладене дозволяє сказати, що в посібнику Г. Даубеншпека йдеться про ті самі питання, але з певним, як зазначає Л. Гуссек, філологічним наголосом, який заслуговує на окрему оцінку. Відзначимо, що реляція не завжди має ототожнюватися з рефератом (доповіддю).

2. Набагато цікавішою $\epsilon$ не філологічна складова частина посібника, оскільки вона бере до уваги особливості німецької юридичної мови, які відсутні в українській юридичній мові, а ії субсумційна частина, яку Р. Алексі разом із деліберативним складником називає основними формами правозастосування: «Зважування $€$ характерною для принципів формою правозастосування. Всупереч цьому правила $є$ нормами, які завжди тільки або можуть бути виконані, або не виконані. Якщо правило чинне і застосовне, то тоді велено робити точно те, що воно вимагає, не більше і не менше. Правила містять у цьому сенсі запровадження у просторі фактично і юридично можливого. Вони не $\epsilon$ ні здатними до зважування, ні такими, що його потребують. Характерною для них формою правозастосування $\epsilon$ субсумція» $[6$, с. 40 ; див. також 7; 8].

У випадку із субсумцією йдеться про схему юридичного аналізу, яка полягає в підведенні факту під норму. Власне кажучи, при цьому йдеться про порівняння обставин справи з елементами фактичного складу норми, тобто про застосування так званих закритих правових норм. у такому разі стає можливо здійснити юридичний аналіз двома способами: або починаючи з аналізу гіпотетичного правового наслідку, йдучи до аналізу елементів фактичного складу, або навпаки. У першому випадку йдеться про експертний стиль опрацювання правової справи, а в другому - про судовий. У структурі посібника першому стилю відповідає другий розділ роботи, а судовому - третій. (Прикметники «експертний» і «судовий» тут потрібно розуміти як данину традиції, насправді ж в обох випадках ідеться про дидактичні, проте не обов'язково університетські, тобто про навчальні в широкому сенсі письмові стилі правового аналізу (пошуку і викладу правового рішення)).

Потрібно відзначити, що реляція являє собою комплексний правовий документ, який містить як матеріально-правові, так і чисто процесуальні аспекти. Робота Г. Даубеншпека повністю відповідає такій комплексній природі реляції. Проте згодом матеріально-правова сторона була емансипована у формі двох згаданих стилів, і тому матеріально-правові дисципліни в Німеччині сьогодні вивчаються за згаданими стилями, а пізніше вони вливаються у навчання складання академічної реляції як такої, тобто комплексної реляції. Слід урахувати, що юридична освіта в Німеччині $€$ двоступеневою: в університеті й на стажуванні в судових та інших органах.

Особливий інтерес при цьому становить експертний стиль опрацювання правової справи. Так, К.-Ф. Штукенберг зазначає, що «в теперішньому повсякденні університетського навчання юристів так званий експертний стиль відіграє центральну роль: студенти першого семестру мусять звикатися, не рідко на превелику силу, з цим способом мислення і манерою говорити, які надалі потрібно застосовувати в майже всіх екзаменаційних роботах, як-от у клаузурах (класних роботах - О.С.) і в домашніх роботах на практичних заняттях, випускних клаузурах i, врешті-решт, на першому іспиті; також у рефендаріаті (підготовча практика, стажування - О.С.) і на другому державному іспиті експертні висновки можуть бути частиною постановки завдання. Викладачі вищої школи проводять, зокрема на практичних заняттях для початківців і для просунутих осіб, де вони ще або знову існують, довгий час за усною демонстрацією і письмовою коректурою експертних розв'язань справ, незважаючи на те, що ініціація в це «мистецтво професії» на перших семестрах у багатьох місцях передається переважно робочим групам, які керуються науковими співробітниками. Іспитовій релевантності експертної техніки відповідає щедра пропозиція дидактичної довідкової літератури у формі статей і книг із загальними настановами і зразковими розв'язаннями справ у різних галузях права. 
у міжнародному порівнянні ця експертна техніка розв'язання справи $\epsilon$ особливістю навчання німецьких юристів. Якщо до іспитових звичаїв інших країн зараховують доволі часто поряд з опитуванням абстрактного знання так само пов'язане з розв'язанням справ обговорювання правових питань, то навіть там, де йдеться про розгляд cas pratique, найчастіше не мають на увазі експертне розв'язання в німецькому розумінні. Обговорення вигаданих обставин справи (hypotheticals), хоч би що там трапляється, скажімо, на іспитах в американських Law Schools, також потрібне issue spotting повинно дотримуватися доступної для пізнання мисленнєвої схеми, однак не досягаючи і приблизно суворої дисципліни експертного стилю. Добра слава, якою користується навчання німецьких юристів за кордоном - іноді більша, ніж усередині країни - ґрунтується також на загальновідомій успішності німецьких юристів в іноземних програмах отримання наукового ступеня, яка, мабуть, чималою мірою завдячує практичним заняттям за експертною технікою» [9, с. 165-166]. А це завдяки і праці Г. Даубеншпека (в актуальній формі).

3. Якщо субсумційний бік реляційної техніки добре розроблений, то цього не можна сказати про деліберативний бік, тобто про реляцію в аспекті зважування (балансування) і принципу пропорційності. Розвиток реляційної техніки в цьому аспекті, тобто щодо так званих відкритих правових норм, містить тільки загальні підходи. I саме в цьому напрямі згадана техніка потребує не тільки потенційної рецепції, але й самостійного розвитку.

у підсумку слід сказати, що згадана реляційна техніка може бути реципована в юридичній навчальній практиці України (з відповідною адаптацією і розвитком, які мають пряме відношення основних форм правозастосування). Ї̈̈ найкраще розроблені аспекти спираються на логічну структуру субсумції, тобто підведення факту під норму, і в цьому сенсі $\epsilon$ інтерсуб'єктивними. Водночас ця техніка має відкриті питання, пов'язані з такою формою правозастосування, як зважування. Розроблення останнього аспекту може надати нове життя реляційній техніці як у Німеччині, так і в Україні.

Подальше дослідження реляційної техніки взагалі та Г. Даубеншпека зокрема можливе в поглибленні матеріально-правового її аспекту, тобто судового та експертного стилів опрацювання правової справи, з одного боку, та в рецепції, адаптації і розвитку реляційної техніки як із погляду субсумції, так із погляду зважування.

\section{ЛITEPATYPA:}

1. Daubenspeck H. Referat, Votum und Urtheil eine Anleitung für praktische Juristen im Vorbereitungsdienst. Berlin : Vahlen, 1884. VIII. 146 S.

2. Schuschke W. Zivilrechtliche Arbeitstechnik im Assessorexamen : Bericht, Votum, Urteil, Aktenvortrag. 35., neu bearb. Aufl. München : Vahlen, 2013. XXII. 492 S.

3. Ranieri F. Relationstechnik, Ueding G. Historisches Wörterbuch der Rhetorik, Bd. 7: Pos-Rhet. Tübingen : Max Niemeyer, 2005. S. 1157-1161.

4. Gusseck L. Zu Relation und Rationalität richterlichen Entscheidens 125 Jahre DaubenspeckSattelmacher: Bericht, Gutachten und Urteil. Festschrift für Ulrich Spellenberg: Zum 70. Geburtstag. München, 2010. S. 83-98.

5. Daubenspeck $\mathrm{H}$. Referat, Votum und Urteil : eine Anleitung für praktische Juristen im Vorbereitungsdienst. 9., verm. und verb. Aufl. Berlin : Vahlen, 1905. VI, 316 S.

6. Alexy R. Idee und Struktur eines vernünftigen Rechtssystems / R. Alexy R. Dreier, U. Neumann (Hg.), Rechts- und Sozialphilosophie in Deutschland heute, Archiv für Rechts- und Sozialphilosophie, Beiheft 44 (1991). S. 30-44.

7. Alexy R. On Balancing and Subsumption. A Structural Comparison. Ratio Juris 16 (2003), S. 433-449.

8. Stück H. Subsumtion und Abwägung // ARSP: Archiv für Rechts- und Sozialphilosophie / Archives for Philosophy of Law and Social Philosophy. 1998. Vol. 84. № 3. S. 405-419.

9. Stuckenberg C.-F. Der juristische Gutachtenstil als cartesische Methode / Georg Freund, Uwe Murmann, René Bloy und Walter Perron (Hrsg.): Grundlagen und Dogmatik des gesamten Strafrechtssystems. FS für Wolfgang Frisch. Berlin, Duncker \& Humblot, 2013. S. 168-177. 